\title{
Efektivitas Pelaksanaan Pemeriksaan Wajib Pajak Orang Pribadi Dalam Rangka Meningkatkan Penerimaan Negara Dari Sektor Pajak Pada Kantor Pelayanan Pajak (KPP) Pratama Palembang llir Barat
}

\author{
Mursalin $^{1}$, Jusmani ${ }^{2}$ \\ ${ }^{1}$ Akuntansi, FE Universitas PGRI Palembang, mursalin@univpgri-palembang.ac.id \\ ${ }^{2}$ Akuntansi, Fakultas Ekonomi, Univ. PGRI Palembang, jusmani@univpgri-palembang.ac.id
}

\begin{abstract}
ABSTRAK
Penelitian ini untuk mengetahui Efektivitas Pelaksanaan Pemeriksaan Wajib Pajak Orang Pribadi dalam Rangka Meningkatkan Penerimaan Negara dari Sektor Pajak pada Kantor Pelayanan Pajak (KPP) Pratama Palembang Ilir Barat. Manfaat penelitian ini bagi akademis dan bagi Pihak Pajak dalam hal ini KPP Pratama Palembang llir Barat. Metode analisis data yang digunakan dalam penelitian ini adalah analisis deskriptif kuantitatif .Data yang digunakan dalam penelitian ini adalah data primer dan data sekunder. Teknik pengumpulan data yaitu wawancara, dokumenasi, dan studi pustaka. Hasil penghitungan efektivitas pelaksanaan pemeriksaan berdasarkan Surat Perintah Pemeriksaan (SP2) yang selesai, dimana tahun 2013-2017 mempunyai tingkat efektivitas yang sama yaitu dalam kriteria efektif dengan persentase $100 \%$. Persentase ini menunjukkan bahwa KPP Pratama Palembang Ilir Barat selalu dapat menyelesaikan Surat Perintah Pemeriksaan (SP2) dalam jangka waktu yang telah ditentukan (satu tahun), artinya tidak ada penumpukan SP2 tahun sebelumnya yang harus diakumulasikan pada tahun berikutnya. Hasil penghitungan efektivitas pelaksanaan pemeriksaan berdasarkan Jumlah Ketetapan Pemeriksaan, dimana tahun 2016-2017 mempunyai tingkat efektivitas tidak efektif $(<69 \%)$ dengan persentase $0,03 \%$ di tahun 2016 dan $4,92 \%$ di tahun 2017. Persentase ini menunjukkan bahwa meskipun terlihat adanya kerjasama yang kooperatif antara petugas pemeriksa dengan Wajib Pajak, tetapi mereka belum memiliki tingkat kesadaran dan kepatuhan terhadap kewajiban perpajakannya.
\end{abstract}

Kata kunci: Efektivitas, Pemeriksaan, Wajib Pajak Orang Pribadi (WPOP)

\section{Pendahuluan}

\section{A. Latar Belakang}

Indonesia saat ini sedang mengalami berbagai permasalahan di berbagai sektor khususnya sektor ekonomi dan untuk tetap dapat bertahan dan memperbaiki kondisi yang ada maka pajak merupakan salah satu potensi penerimaan dalam negeri yang menjadi prioritas utama karena mampu mendominasi penerimaan negara.

Pembayaran pajak merupakan perwujudan dari kewajiban kenegaraan dan peran serta masyarakat secara langsung yang bersama-sama $\begin{array}{lrr}\text { mengumpulkan dana } & \text { untuk } \\ \text { pembiayaan } & \text { negara } & \text { dan }\end{array}$ pembangunan nasional.

Indonesia saat ini dalam melaksanakan pemungutan pajak menurut undang-undang menganut sistem self assessment. Sistem pemungutan ini mempunyai arti bahwa besarnya pajak yang terutang dipercayakan kepada Wajib Pajak (WP) itu sendiri, dimana Wajib Pajak harus melaporkan secara teratur seluruh jumlah pajak yang terutang dan jumlah pajak yang telah ditentukan dalam peraturan perundang-undangan perpajakan. Untuk mendukung 
keberhasilan diterapkannya sistem self assessment salah satu hal mendasar yang harus dilakukan adalah melaksanakan penegakan hukum (law enforcement) perpajakan.

Oleh karena itu terhadap Wajib Pajak yang melakukan kecurangan dan lalai akan pemenuhan kewajibannya perlu dilakukan pemeriksaan untuk menguji kepatuhan dan menegakkan peraturan perpajakan (law enforcement) yang mempunyai kekuatan hukum memaksa sesuai dengan prosedur yang telah ditetapkan dalam UU perpajakan.

\section{B. Batasan Masalah}

Permasalahan dalam penelitian ini dibatasi pada penerimaan pajak khususnya PPh Orang Pribadi di KPP Pratama Palembang Ilir Barat sebagai hasil dari pelaksanaan pemeriksaan yang dilakukan terhadap Wajib Pajak dan periode penelitian yang diambil yaitu dari tahun 2013 sampai tahun 2017.

\section{Rumusan Masalah}

Rumusan masalah dalam penelitian ini adalah "Bagaimana Efektivitas Pelaksanaan Pemeriksaan Wajib Pajak Orang Pribadi dalam Rangka Meningkatkan Penerimaan Negara dari Sektor Pajak pada Kantor Pelayanan Pajak (KPP) Pratama Palembang Ilir Barat?"

\section{Tinjauan Teori}

A. Tinjauan Umum tentang Pajak

1. Pengertian Pajak

Soemitro menyatakan bahwa pajak adalah iuran pajak kepada kas negara berdasarkan undang-undang (yang dapat disahkan) dengan tidak mendapat jasa timbal (kontraprestasi), yang langsung dapat ditujukan dan yang digunakan untuk membayar pengeluaran umum (Resmi, 2014:1-2).
Menurut Feldmann dalam pengertian pajak adalah pajak adalah prestasi yang dipaksakan sepihak oleh dan terutang kepada penguasa (menurut norma-norma yang ditetapkan secara umum), tanpa adanya kontraprestasi, dan sematamata digunakan untuk menutup pengeluran-pengeluaran umum (Resmi, 2014:1-2).

\section{Fungsi dan Peranan Pajak}

Menurut Resmi (2014:3) sebagaimana telah diketahui ciri-ciri yang melekat pada pengertian pajak dari berbagai pengertian, terlihat adanya fungsi pajak yaitu:

a. Fungsi Penerimaan (Budgetair)

Pajak berfungsi sebagai salah satu sumber penerimaan pemerintah untuk membiayai pengeluaran baik rutin maupun pembangunan. Sebagai sumber keuangan negara, pemerintah berupaya memasukkan uang sebanyak-banyaknya untuk kas negara.

b. Fungsi Mengatur (Regulered)

Pajak berfungsi sebagai alat untuk mengatur atau melaksanakan kebijakan pemerintah dalam bidang sosial dan ekonomi serta mencapa tujuan-tujuan tertentu di luar bidang keuangan.

Pemungutan pajak merupakan perwujudan dari pengabdian kewajiban dan peran serta wajib pajak yang secara langsung dan bersama-sama melaksanakan kewajiban perpajakan yang diperlukan untuk pembiayaan negara dan pembangunan nasional. Untuk meningkatkan pendapatan negara melalui pajak tersebut diperlukan berbagai upaya. Upayaupaya tersebut salah satunya melalui penegakan hukum (law enforcement) yang terdiri atas pemeriksaan, penyidikan, dan penagihan pajak. Pemeriksaan pajak merupakan instrumen untuk menentukan 
kepatuhan, baik formal maupun material, yang tujuan utamanya adalah untuk menguji dan meningkatkan tax compliance seorang Wajib Pajak.

\section{Sistem Pemungutan Pajak}

Menurut Resmi (2014:11) dalam memungut pajak dikenal beberapa sistem pemungutan, yaitu:

a. Official Assessment System

Sistem pemungutan pajak yang memberi kewenangan aparatur perpajakan untuk menentukan sendiri jumlah pajak yang terutang setiap tahunnya sesuai dengan peraturan perundang-undangan perpajakan yang berlaku. Dalam sistem ini, inisiatif serta kegiatan menghitung dan memungut pajak sepenuhnya berada di tangan para aparatur perpajakan.

b. Self Assessment System

Sistem pemungutan pajak yang memberi wewenang Wajib Pajak dalam menentukan sendiri jumlah pajak yang terutang setiap tahunnya sesuai dengan peraturan perundangundangan perpajakan yang berlaku. Dalam sistem ini, inisiatif serta kegiatan menghitung dan memungut pajak sepenuhnya berada di tangan Wajib Pajak.

c. With Holding System

Sistem pemungutan pajak yang memberi wewenang kepada pihak ketiga yang ditunjuk untuk menentukan besarnya pajak yang terutang oleh Wajib Pajak sesuai dengan peraturan perundang-undangan perpajakan yang berlaku. Penunjukan pihak ketiga ini dilakukan sesuai peraturan perundangundangan perpajakan, keputusan presiden, dan peraturan lainnya untuk memotong serta memungut pajak, menyetor, dan mempertanggungjawabkan melalui sarana perpajakan yang tersedia.

\section{Hambatan Pemungutan Pajak}

Menurut Mardiasmo (2009:8-9) hambatan terhadap pemungutan pajak dapat dikelompokkan menjadi:

a. Perlawanan Pasif

1) Masyarakat enggan (pasif) membayar pajak, yang dapat disebabkan antara lain:

2) Perkembangan intelektual dan moral masyarakat.

3) Sistem perpajakan yang (mungkin) sulit dipahami masyarakat.

4) Sistem kontrol tidak dapat dilakukan atau dilaksanakan dengan baik.

b. Perlawanan Aktif

1) Perlawanan aktif meliputi semua usaha dan perbuatan yang secara langsung ditujukan kepada fiskus dengan tujuan untuk menghindari pajak. Bentuknya antara lain:
a) Tax avoidance, usaha meringankan beban pajak dengan tidak melanggar undan undang.
b) Tax evasion, usaha meringankan beban pajak dengan cara melanggar undang-undang (menggelapkan pajak).

\section{Sanksi Pajak}

Dalam undang-undang perpajakan dikenal dua macam sanksi, yaitu sanksi administrasi dan sanksi pidana. Ancaman terhadap pelanggaran suatu norma perpajakan ada yang diancam dengan sanksi administrasi saja, ada yang diancam dengan pidana saja, dan ada pula yang diancam dengan sanksi administrasi dan sanksi pidana.

\section{Wajib Pajak Orang Pribadi}

Menurut Undang-undang Republik Indonesia Nomor 6 Tahun 1983 tentang Ketentuan Umum dan 
Tata Cara Perpajakan Sebagaimana Telah Beberapa Kali Diubah Terakhir Dengan Undang-undang Republik Indonesia Nomor 16 Tahun 2009 pasal 1 ayat 2 bahwa Wajib Pajak adalah orang pribadi atau badan, meliputi pembayar pajak, pemotong pajak, dan pemungut pajak, yang mempunyai hak dan kewajiban perpajakan sesuai dengan ketentuan peraturan perundang-undangan perpajakan.

Selanjutnya, Wajib Pajak Orang Pribadi adalah orang yang memperoleh penghasilan baik sebagai seorang direktur dari satu, beberapa, atau bahkan ratusan perusahaan atau seorang pemegang saham atau komisaris atau pegawai menengah atau pegawai rendah atau pekerja mandiri seperti dokter, notaris, dan pengacara.

Wajib Pajak Orang Pribadi melaporkan penghasilannya dengan mengisi dan memasukkan SPT Wajib Pajak Orang Pribadi. Penghasilan yang dilaporkan biasanya terdiri dari penghasilan dari usaha adalah penghasilan yang diperoleh dari kegiatan usaha seperti berdagang atau memproduksi barang atau produk tertentu. Penghasilan dari pekerjaan bebas adalah penghasilan yang diperoleh dari kegiatan dalam profesi tertentu seperti dokter, pengacara, notaris/PPAT, konsultan, dan sebagainya.

\section{Jenis-jenis Pajak yang Dilakukan Pemeriksaan pada KPP}

Jenis pajak yang dilakukan pemeriksaan pada Kantor Pelayanan Pajak (KPP) Pratama Palembang Ilir Barat sejak tahun 2012 hanya terdiri atas 3 (tiga) jenis yaitu:

a. Pajak Penghasilan (PPh)

PPh adalah pajak yang

dikenakan kepada orang pribadi atau badan atas penghasilan yang diterima atau diperoleh dalam satu Tahun Pajak. Penghasilan adalah setiap tambahan kemampuan ekonomis yang berasal baik dari Indonesia maupun dari luar Indonesia yang dapat digunakan untuk konsumsi atau untuk menambah kekayaan dengan nama dan dalam bentuk apapun. Dengan demikian maka penghasilan itu dapat berupa keuntungan usaha, gaji, honorarium, hadiah, dan lain sebagainya.

b. Pajak Pertambahan Nilai (PPN)

PPN adalah pajak yang dikenakan atas impor atau penyerahan Barang Kena Pajak atau Jasa Kena Pajak di dalam Daerah Pabean. Yang dimaksud Daerah Pabean adalah wilayah Republik Indonesia yang meliputi wilayah darat, perairan, dan ruang udara yang ada diatasnya. Mengingat PPN mempengaruhi penentuan harga barang dan jasa maka atas impor atau penyerahan barang-barang kebutuhan pokok tidak dikenakan PPN. Demikian juga atas penyerahan jasa-jasa tertentu seperti jasa di bidang pelayanan kesehatan medik, pelayanan sosial, pendidikan, keagamaan, angkutan umum di darat dan air, dan di bidang tenaga kerja ditetapkan sebagai jenis jasa yang tidak dikenakan PPN.

c. Pajak Penjualan atas Barang Mewah (PPnBM)

PPnBM dikenakan sebagai tambahan pengenaan PPN yaitu atas impor atau penyerahan Barang Kena Pajak yang Tergolong Mewah di dalam Daerah Pabean, misalnya atas penyerahan mobil sedan, rumah di atas $200 \mathrm{~m}^{2}$ dan barang-barang mewah lainnya sesuai dengan ketentuan. 


\section{B. Tinjauan Umum tentang Pemeriksaan Pajak}

1. Pengertian Pemeriksaan Pajak

Pengertian pemeriksaan telah diatur dalam Peraturan Menteri Keuangan Republik Indonesia Nomor: 17/PMK.03/2013 tentang Tata Cara Pemeriksaan pasal 1 ayat 2 yang menyatakan bahwa pemeriksaan adalah serangkaian kegiatan menghimpun dan mengolah data, keterangan, dan/atau bukti yang dilaksanakan secara objektif dan profesional berdasarkan suatu standar pemeriksaan untuk menguji kepatuhan pemenuhan kewajiban perpajakan dan/atau untuk tujuan lain dalam rangka melaksanakan ketentuan peraturan perundang undangan perpajakan.

Berdasarkan pengertian di atas, maka fokus pemeriksaan pajak adalah pada ketaatan (compliance) Wajib Pajak dalam menjalankan asas self assessment, yaitu mengisi, menghitung, memperhitungkan, memungut, memotong, dan melaporkan seluruh kewajiban perpajakan sesuai dengan ketentuan yang berlaku.

\section{Tujuan Pemeriksaan Pajak}

Sesuai dengan Peraturan Menteri Keuangan Republik Indonesia Nomor: 17/PMK.03/2013 tentang Tata Cara Pemeriksaan pasal 2 bahwa tujuan pemeriksaan adalah menguji kepatuhan pemenuhan kewajiban perpajakan dan/ atau untuk tujuan lain dalam rangka melaksanakan ketentuan peraturan perundangundangan perpajakan.

Pemeriksaan yang bertujuan untuk menguji kepatuhan pemenuhan kewajiban perpajakan seorang Wajib Pajak dapat dilakukan dalam hal:

a. SPT lebih bayar termasuk yang telah diberikan pengembalian pendahuluan pajak. b. SPT rugi.

c. SPT tidak atau terlambat (melampaui jangka waktu yang ditetapkan dalam Surat Teguran) disampaikan.

d. Melakukan penggabungan, peleburan, pemekaran, likuidasi, pembubaran, atau akan meninggalkan Indonesia untuk selama-lamanya, atau

e. Menyampaikan SPT yang memenuhi kriteria seleksi berdasarkan hasil analisis (risk based selection) mengindikasikan adanya kewajiban perpajakan Wajib Pajak yang tidak dipenuhi sesuai ketentuan peraturan perundang-undangan perpajakan.

\section{Ruang Lingkup Pemeriksaan}

Ruang lingkup pemeriksaan menentukan luas dan kedalaman pemeriksaan. Penentuan ruang lingkup akan mempengaruhi teknik pemeriksaan yang akan diterapkan, jangka waktu pemeriksaan, dan sasaran atau jenis yang diperiksa, ruang lingkup pemeriksaan pajak dapat dibedakan menjadi pemeriksaan lapangan dan pemeriksaan kantor.

Pemeriksaan Kantor dilakukan dalam jangka waktu paling lama 3 (tiga) bulan dan dapat diperpanjang menjadi 6 (enam) bulan yang dihitung sejak tanggal Wajib Pajak datang memenuhi surat panggilan dalam rangka Pemeriksaan Kantor sampai dengan tanggal Laporan Hasil Pemeriksaan.

\section{Pemeriksaan}

Lapangan dilakukan dalam jangka waktu paling lama 4 (empat) bulan dan dapat diperpanjang menjadi paling lama 8 (delapan) bulan yang dihitung sejak tanggal Surat Perintah Pemeriksaan sampai dengan tanggal Laporan Hasil Pemeriksaan. 


\section{Jenis Pemeriksaan Pajak}

Menurut Bwoga (2006:17), jenisjenis pemeriksaan tersebut secara ringkas dapat dijelaskan sebagai berikut:

\section{a. Pemeriksaan Rutin}

Pemeriksaan rutin adalah pemeriksaan yang bersifat rutin yang dilakukan terhadap Wajib Pajak sehubungan dengan pemenuhan hak dan kewajiban perpajakannya.

b. Pemeriksaan Kriteria Seleksi

Pemeriksaan yang dilakukan terhadap Wajib Pajak badan atau Wajib Pajak orang pribadi yang terpilih berdasarkan skor resiko tingkat kepatuhan secara komputerisasi.

c. Pemeriksaan Khusus

Pemeriksaan yang secara khusus dilakukan terhadap Wajib Pajak sehubungan dengan adanya data, informasi, laporan atau pengaduan yang berkaitan dengan Wajib Pajak tersebut, atau untuk memperoleh data atau informasi untuk tujuan tertentu lainnya.

d. Pemeriksaan Wajib Pajak Lokasi Pemeriksaan yang dilakukan terhadap cabang, perwakilan, pabrik dan atau tempat usaha yang pada umumnya berbeda lokasinya dengan Wajib Pajak domisili.

e. Pemeriksaan Tahun Berjalan

Pemeriksaan yang dilakukan dalam tahun berjalan terhadap Wajib Pajak untuk jenis-jenis pajak tertentu atau untuk seluruh jenis pajak dapat dilakukan terhadap Wajib Pajak domisili atau Wajib Pajak lokasi. Pelaksanaan pemeriksaan tahun berjalan ini hanya dapat dilakukan terhadap masa pajak sampai dengan bulan Oktober dari tahun pajak yang bersangkutan.

f. Pemeriksaan Bukti Permulaan

Pemeriksaan yang dilakukan untuk mendapatkan bukti permulaan tentang adanya dugaan telah terjadi tindak pidana di bidang perpajakan.

\section{Kantor Pelaksana Pemeriksaan Pajak}

Secara struktural tugas pemeriksaan pajak berada di bawah koordinasi Direktorat Pemeriksaan Pajak yang secara operasional dilakukan oleh para pejabat fungsional pemeriksa pajak yang tersebar di Direktorat Pemeriksaan Pajak (Ditrikpa), Kantor-kantor Wilayah (Kanwil) Direktorat Jenderal Pajak, Kantor-kantor Pemeriksaan dan Penyidikan Pajak (Karikpa), dan Kantor-kantor Pelayanan Pajak (KPP) di seluruh Indonesia.

KPP merupakan pelaksana pemeriksaan sederhana, sedangkan Karikpa dan Kanwil merupakan pelaksana pemeriksaan lengkap. Masing-masing Kanwil, Karikpa, dan KPP mempunyai batas wilayah yang menjadi wewenangnya masingmasing. Umumnya, batas wilayah satu KPP di luar Palembang adalah meliputi satu atau lebih kabupaten/kota. Sedangkan, batas wilayah KPP di Palembang adalah meliputi satu atau lebih kecamatan.

Batas wilayah satu Karikpa adalah meliputi batas wilayah untuk satu atau lebih KPP yang menjadi mitra kerjanya. Batas wilayah Kanwil adalah wilayah beberapa KPP yang menjadi bawahannya yang biasanya di dalam satu atau lebih provinsi. Batas wilayah Ditrikpa sudah tentu lebih luas lagi, yaitu nasional. Berdasarkan pembagian batas wilayah tersebut, Wajib Pajak yang berdomisili dan atau berlokasi atau Karikpa atau Kanwil atau Ditrikpa, tergantung ruang lingkup, dan penugasan pemeriksaan. 


\section{Petugas \\ Pemeriksaan Pajak \\ Menurut Peraturan Menteri} Keuangan Republik Indonesia Nomor: 17/PMK.03/2013 tentang Tata Cara Pemeriksaan pasal 1 ayat 6 bahwa Pemeriksa Pajak adalah Pegawai Negeri Sipil di lingkungan Direktorat Jenderal Pajak atau tenaga ahli yang ditunjuk oleh Direktur Jenderal Pajak, yang diberi tugas, wewenang, dan tanggung jawab untuk melaksanakan Pemeriksaan.

\section{Objek Pemeriksaan Pajak}

Objek pemeriksaan menurut Priantara (2002:33), pada umumnya adalah Surat Pemberitahuan (SPT) Tahunan dan atau SPT Masa beserta lampiran-lampirannya. SPT Tahunan adalah surat yang digunakan Wajib Pajak untuk melaporkan penghitungan dan pembayaran pajak yang terutang dalam suatu tahun pajak dan SPT Masa adalah surat yang digunakan Wajib Pajak/Penghasilan Kena Pajak (PKP) untuk melaporkan penghitungan dan atau pembayaran pajak terutang dalam suatu masa pajak. Lampiranlampiran SPT meliputi laporan keuangan, daftar perhitungan penyusutan/amortisasi fiskal, Surat Setoran Pajak (SSP), dan lain-lain. SPT dan lampiran-lampirannya akan menjadi tolak ukur kepatuhan Wajib Pajak.

\section{Tinjauan Umum tentang Efektivitas}

Efektivitas artinya informasi harus sesuai dengan kebutuhan pemakai dalam mendukung suatu proses bisnis, termasuk di dalamnya informasi tersebut harus disajikan dalam waktu yang tepat, format yang tepat sehingga dapat dipahami, konsisten dengan format sebelumnya, isinya sesuai dengan kebutuhan saat ini dan lengkap atau sesuai dengan kebutuhan dan ketentuan. (Mc Leod dalam Susanto, 2007:41).

\section{Kerangka Berpikir Gambar 1 Kerangka Berpikir}

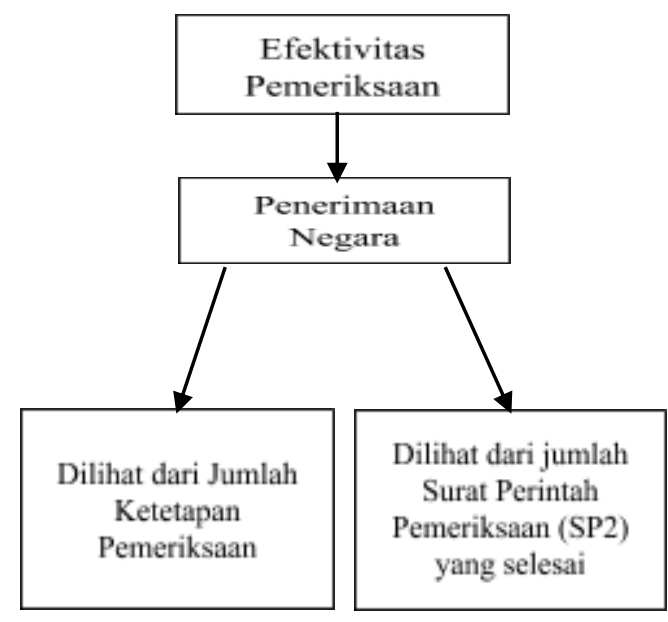

III. Prosedur Penelitian

A. Metode Penelitian

Metode penelitian yang digunakan adalah deskriptif kuantitatif. Menurut Bondan dan Taylor seperti dikutip oleh Moleong (2011:3), penelitian deskriptif didefinisikan sebagai suatu prosedur penelitian yang menghasilkan data berupa katakata tertulis atau lisan dari orang-orang dan perilaku yang diamati. Menurut Nazir (2011:4), penelitian deskriptif adalah suatu metode dalam meneliti status kelompok manusia, suatu objek, suatu set kondisi, suatu sistem pemikiran, ataupun suatu kelas peristiwa pada masa sekarang.

Penggunaan jenis penelitian deskriptif kuantitatif dalam penelitian ini diharapkan mampu memberikan gambaran melalui penghitungan dari data-data yang diperoleh mengenai efektivitas pelaksanaan pemeriksaan untuk meningkatkan penerimaan negara dari sektor pajak di KPP Pratama Palembang Ilir Barat.

\section{B. Objek Penelitian}

Penelitian ini dilakukan di Kota Palembang yaitu pada KPP Pratama 
Palembang Ilir Barat, khususnya pada seksi PPh Orang Pribadi yang mengurusi pemeriksaan terhadap Wajib Pajak yang lalai dalam pemenuhan kewajiban perpajakannya.

\section{Populasi dan Sampel \\ 1. Populasi}

Populasi dalam penelitian ini adalah Surat Perintah Pemeriksaan (SP2) dan penerimaan atas hasil pemeriksaan dengan didasarkan pada jumlah target dan realisasi ketetapan pemeriksaan di KPP Pratama Palembang llir Barat.

\section{Sampel}

Sampel dalam penelitian ini adalah:

a. Surat Perintah Pemeriksaan (SP2) selesai mulai tahun 2013 sampai tahun 2017 di KPP Pratama Palembang llir Barat.

b. Jumlah target dan realisasi ketetapan pemeriksaan mulai dari tahun 2013 sampai tahun 2017 di KPP Pratama Palembang Ilir Barat.

\section{Variabel Penelitian}

Dalam penelitian ini yang menjadi variabel penelitian adalah efektivitas pelaksanaan pemeriksaan untuk meningkatkan penerimaan negara dari sektor pajak pada KPP Pratama Palembang Ilir Barat.

\section{E. Instrumen Penelitian}

Sehubungan dengan pokok masalah yang dibahas dapat dikemukakan definisi operasional variabel yang akan dijadikan acuan sebagai berikut:

1. Efektivitas merupakan suatu ukuran yang memberikan gambaran seberapa jauh target dapat dicapai. Pengertian efektivitas ini lebih berorientasi kepada keluaran sedangkan masalah penggunaan masukan kurang menjadi perhatian utama. Apabila efisiensi dikaitkan dengan efektivitas maka walaupun terjadi peningkatan efektivitas belum tentu efisiensi meningkat (Sedarmayanti, 2009:59).

2. Pemeriksaanadalah serangkaian kegiatan menghimpun dan mengolah data, keterangan, dan/atau bukti yang dilaksanakan secara objektif dan profesional berdasarkan suatu standar pemeriksaan untuk menguji kepatuhan pemenuhan kewajiban perpajakan dan/ atau untuk tujuan lain dalam rangka melaksanakan ketentuan peraturan perundang undangan perpajakan (Peraturan Menteri Keuangan Republik Indonesia Nomor: 17/PMK.03/2013 tentang Tata Cara Pemeriksaan pasal 1 ayat 2).

\section{F. Sumber Data dan Teknik Pengumpulan Data}

1. Sumber Data

a. Sumber Data Primer, merupakan sumber data dimana data yang diperoleh berasal langsung dari sumbernya seperti melakukan wawancara yang dapat menghasilkan data tertulis maupun data hasil wawancara dengan pihak KPP Pratama Palembang llir Barat. Yang dijadikan responden dari penelitian ini adalah: Kepala Seksi Penagihan, Koordinator Pelaksana Seksi PPh Orang Pribadi, dan Unit Pelaksana Pemeriksaan Pajak.

b. Sumber Data Sekunder, data sekunder dapat berupa arsip atau dokumen yang dimiliki oleh KPP Pratama Palembang Ilir Barat, misalnya jumlah penerimaan pajak dan informasi yang diperoleh dari studi pustaka untuk beberapa teori yang berkaitan dengan permasalahan.

\section{Teknik Pengumpulan Data}

Teknik pengumpulan data yang digunakan dalam penelitian ini adalah 
wawancara, dokumentasi dan studi pustaka.

\section{G. Metode Analisis Data}

Dalam analisis data ini peneliti hanya terbatas pada perhitungan persentase yang selanjutnya menggunakan pemikiran logis untuk menggambarkan, menjelaskan, dan menguraikan secara mendalam dan sistematis tentang keadaan yang sebenarnya, kemudian ditarik suatu kesimpulan sehingga dapat diperoleh suatu penyelesaian atas permasalahan yang ada.

Dari

segi penyelesaian pemeriksaan yang didasarkan pada pencapaian target dan realisasi atas jumlah Surat Perintah Pemeriksaan (SP2) yang selesai setiap tahunnya dengan menggunakan perhitungan sebagai berikut:

$$
\text { Efektivitas }=\frac{\text { Realisasi pemeriksaan }}{\text { TargetPemeriksaan }+\mathrm{n}} \times 100 \%
$$

Dari segi penerimaan atas hasil pemeriksaan yang didasarkan pada pencapaian target dan realisasi atas ketetapan pemeriksaan setiap tahunnya dengan menggunakan rumus sebagai berikut:

$$
\text { Efektivitas }=\frac{\text { Realisasi pemeriksaan }}{\text { TargetPemeriksaan }+\mathrm{n}} \times 100 \%
$$

Dimana $\mathrm{n}=$ jumlah tunggakan yang terjadi di tahun sebelumnya jika ada.

Menurut Siagian (2014:234), untuk mengukur tingkat efektivitas dari suatu sistem kerja dapat juga dengan memberikan peringkat dengan menggunakan skala peringkat. Skala peringkat yang digunakan adalah: (dalam persentase)

1. $>100$ sangat efektif

2. $90-100$ efektif
3. 80 - 89 cukup efektif

4. $70-79$ kurang efektif

5. $<69$ tidak efektif

Dari hasil analisis data tersebut, jika tingkat efektivitas yang diperoleh peneliti menunjukkan jumlah persentase yang melebihi $100 \%$ dan semakin meningkat dari tahun ke tahun secara signifikan, maka pelaksanaan pemeriksaan rutin yang dilakukan oleh KPP Pratama Palembang Ilir Barat dalam hal ini dikatakan sangat efektif atau sangat baik.

Namun demikian tinggi rendahnya efektivitas tidak ada ukuran yang pasti karena efektivitas relatif dipengaruhi oleh banyak faktor antara lain dari potensi daerah yang dimiliki, organisasi yang mengelola penerimaan, dan pihak pelaksana atas tindakan pemeriksaan pajak.

\section{HASIL PENELITIAN DAN PEMBAHASAN}

A. Hasil Penelitian

1. Perkembangan Penerimaan KPP Pratama Palembang Ilir Barat

Penerimaan pajak di KPP Pratama Palembang llir Barat setiap tahun meningkat, akan tetapi tidak setiap tahun bisa melebihi target yang telah ditentukan, dimana hal ini dapat dilihat dari Tabel 1 Target dan Realisasi Penerimaan Pajak KPP Pratama Palembang llir Barat pada tahun 2013-2017 sebagai berikut:

Tabel 1

Target dan Realisasi Penerimaan Pajak KPP Pratama Palembang llir Barat Tahun 2013-2017

\begin{tabular}{|c|c|c|c|}
\hline Tahun & Target (Rp) & Realisasi (Rp) & Selisih (Rp) \\
\hline 2013 & 368.096 .000 .000 & 406.017 .770 .000 & 37.921 .770 .000 \\
\hline 2014 & 406.982 .770 .000 & 467.497 .150 .000 & 60.514 .380 .000 \\
\hline 2015 & 527.716 .650 .000 & 576.886 .390 .000 & 49.169 .740 .000 \\
\hline 2016 & 764.762 .620 .000 & 633.149 .220 .000 & $(131.613 .400 .000)$ \\
\hline 2017 & 707.805 .550 .000 & 746.880 .070 .000 & 39.074 .520 .000 \\
\hline
\end{tabular}


Dari Tabel 1 tersebut dapat dilihat bahwa target penerimaan pajak secara keseluruhan di tahun 2013 yang menjadi tanggungjawab KPP Pratama Palembang Ilir Barat adalah sebesar Rp 368.096.000.000 dimana target tersebut tercapai sesuai dengan yang diinginkan yaitu sebesar $R p$ 406.017.000.000. Terdapat selisih angka positif sebesar $\mathrm{Rp}$ 37.921.770.000.

Sedangkan di tahun 2014 yang menjadi tanggungjawab KPP Pratama Palembang Ilir Barat adalah sebesar Rp 406.982.770.000 dimana target tersebut tercapai sesuai dengan yang diinginkan yaitu sebesar $\mathrm{Rp}$ 467.497.150.000. Terdapat selisih angka positif sebesar $\mathrm{Rp}$ 60.514.380.000.

Di tahun 2015 yang menjadi tanggungjawab KPP Pratama Palembang Ilir Barat adalah sebesar Rp 527.716.650.000 dimana target tersebut tercapai sesuai dengan yang diinginkan yaitu sebesar $\mathrm{Rp}$ 576.886.390.000. Terdapat selisih angka positif sebesar $\mathrm{Rp}$ 49.169.740.000.

Selanjutnya di tahun 2016 yang menjadi tanggungjawab KPP Pratama Palembang Ilir Barat adalah sebesar Rp 764.762.620.000 dimana target tersebut tidak tercapai sesuai dengan yang diinginkan yaitu sebesar $R p$ 633.149.220.000. Terdapat selisih angka negatif sebesar (Rp 131.613.400.000).

Terakhir di tahun 2017 yang menjadi tanggungjawab KPP Pratama Palembang Ilir Barat adalah sebesar Rp 707.805.550.000 dimana target tersebut tercapai sesuai dengan yang diinginkan yaitu sebesar $R p$ 746.880.070.000. Terdapat selisih angka positif sebesar $\mathrm{Rp}$ 39.074.520.000.

Dari sisi pertumbuhan penerimaan pajak di KPP Pratama
Palembang Ilir Barat seperti yang diuraikan di atas pada tahun 20132017 mengalami peningkatan yang signifikan, karena Wajib Pajak besar lebih banyak yang patuh melaksanakan kewajiban perpajakannya dari pada yang tidak patuh.

\section{Kontribusi Penerimaan dari Pelaksanaan Pemeriksaan PPh Orang Pribadi Terhadap Penerimaan PPh Orang Pribadi di KPP Pratama Palembang Ilir Barat}

Kontribusi penerimaan dari pelaksanaan pemeriksaan PPh Orang Pribadi terhadap penerimaan PPh Orang Pribadi di KPP Pratama Palembang llir Barat dari tahun 20132017, terlihat di bawah ini:

Tabel 2

Kontribusi Penerimaan dari Pelaksanaan Pemeriksaan PPh Orang Pribadi

Terhadap Penerimaan PPh Orang Pribadi Tahun 2010-2014

KPP Pratama Palembang Ilir Barat

\begin{tabular}{|c|r|r|r|}
\hline Tahun & $\begin{array}{c}\text { Penerimaan dari } \\
\text { Pelaksanaan } \\
\text { Pemeriksaan } \\
\text { PPh Orang } \\
\text { Pribadi (Rp) }\end{array}$ & $\begin{array}{c}\text { Penerimaan } \\
\text { PPh Orang } \\
\text { Pribadi (Rp) }\end{array}$ & $\begin{array}{c}\% \\
\text { Kontribusi } \\
\text { Penerimaan }\end{array}$ \\
\hline 2013 & - & 4.276 .127 .161 & - \\
\hline 2014 & - & 4.172 .608 .104 & - \\
\hline 2015 & - & 5.000 .489 .573 & 0,13 \\
\hline 2016 & 7.445 .745 & 5.932 .971 .678 & 9,00 \\
\hline 2017 & 540.723 .373 & 6.009 .324 .221 & - \\
\hline
\end{tabular}

Sumber: KPP Pratama Palembang Ilir Barat (diolah)

Dari Tabel 2 dapat diketahui bahwa kontribusi penerimaan dari pelaksanaan pemeriksaan pajak di KPP Pratama Palembang Ilir Barat mengalami peningkatan dimana pada tahun 2016 kontribusinya sebesar $0,13 \%$, menjadi $9,00 \%$ pada tahun 2017. Jadi secara keseluruhan ratarata kontribusi yang diberikan atas realisasi pemeriksaan terhadap penerimaan pajak di KPP Pratama Palembang Ilir Barat selama 2 (dua) tahun terakhir sebesar 4,57\%. Angka ini memperlihatkan upaya yang dilakukan KPP Pratama Palembang Ilir 
Barat belum optimal, masih bisa ditingkatkan lagi dengan cara meningkatkan kualitas dan kuantitas kerja petugas pemeriksa pajak itu sendiri.

\section{Pelaksanaan Pemeriksaan di} KPP Pratama Palembang Ilir Barat

Pemeriksaan dilakukan dengan pedoman pada norma pemeriksaan yang berkaitan dengan pemeriksaan pajak, pemeriksaan, dan Wajib Pajak yang dilakukan pemeriksaan dilakukan berdasarkan Surat Perintah Pemeriksaan (SP2).

Pemeriksaan dinyatakan dimulai jika Surat Perintah Pemeriksaan (SP2) yang dilampiri dengan Surat Pemberitahuan Pemeriksaan yang harus disampaikan kepada Wajib Pajak yang bersangkutan dan telah diterima.

\section{B. Pembahasan}

1. Target dan Realisasi Surat Perintah Pemeriksaan (SP2) dan Jumlah Ketetapan Pemeriksaan

Target dan realisasi Surat Perintah Pemeriksaan (SP2) dan Jumlah Ketetapan Pemeriksaan dapat dilihat dalam Tabel 3 dan Tabel 4 sebagai berikut:

Tabel 3

Data Penyelesaian SP2 PPh Orang Pribadi

KPP Pratama Palembang llir Barat (dalam aktivitas)

\begin{tabular}{|l|r|r|r|r|}
\hline Tahun & $\begin{array}{r}\text { Saldo } \\
\text { Awal }\end{array}$ & Target & Realisasi & $\begin{array}{r}\text { Saldo } \\
\text { Akhir }\end{array}$ \\
\hline 2013 & 0 & 41 & 41 & 0 \\
\hline 2014 & 0 & 20 & 20 & 0 \\
\hline 2015 & 0 & 25 & 25 & 0 \\
\hline 2016 & 0 & 68 & 68 & 0 \\
\hline 2017 & 0 & 79 & 79 & 0 \\
\hline
\end{tabular}

Sumber: KPP Pratama Palembang llir Barat (diolah)
Tabel 4

Data Target dan Realisasi Jumlah Ketetapan Pemeriksaan PPh Orang Pribadi KPP Pratama Palembang Ilir Barat

\begin{tabular}{|c|r|r|}
\hline Tahun & Target (Rp) & Realisasi (Rp) \\
\hline 2013 & - & - \\
\hline 2014 & 6.711 .050 .672 & - \\
\hline 2015 & 10.900 .490 .093 & - \\
\hline 2016 & 29.440 .524 .488 & 7.445 .745 \\
\hline 2017 & 11.000 .000 .000 & 540.723 .373 \\
\hline
\end{tabular}

Sumber: KPP Pratama Palembang llir Barat (diolah)

Dari Tabel 3 dapat dilihat adanya penurunan Surat Perintah Pemeriksaan (SP2) yang diterbitkan oleh KPP Pratama Palembang Ilir Barat setiap tahunnya dari tahun 2013 ke tahun 2015, namun ada kenaikan di tahun 2016 dan 2017. Walaupun demikian KPP Pratama Palembang Ilir Barat bisa menyelesaikan SP2 tersebut sehingga tidak menimbulkan beban pekerjaan pada tahun berikutnya.

Dari Tabel 4 diketahui bahwa KPP Pratama Palembang Ilir Barat pada tahun 2017 telah dapat menaikkan penerimaan PPh Orang Pribadi berdasarkan Jumlah Ketetapan Pemeriksaan sebesar Rp 540.723.373 dibandingkan tahun 2016 sebesar Rp 7.445.745.

\section{Perhitungan Efektivitas Pelaksanaan Pemeriksaan}

Efektivitas

pelaksanaan pemeriksaan dari segi waktu penyelesaian dengan berdasarkan target ditambah saldo tunggakan jika ada, dan realisasi atas SP2 dan Jumlah Ketetapan Pemeriksaan.

\section{a. Penghitungan \\ Pelaksanaan Berdasarkan SP2 \\ Penghitungan pelaksanaan}


berdasarkan SP2 dari tahun 20132017 adalah sebagai berikut:

1) Tahun 2013

Efektivitas $=\frac{41}{41} \times 100 \%=100 \%$

2) Tahun 2014

Efektivitas $=\frac{20}{20} \times 100 \%=100 \%$

3) Tahun 2015

Efektivitas $=\frac{25}{25} \times 100 \%=100 \%$

4) Tahun 2016

Efektivitas $=\frac{68}{68} \times 100 \%=100 \%$

5) Tahun 2017

Efektivitas $=\frac{79}{79} \times 100 \%=100 \%$

Dari hasil penghitungan di atas, dapat diketahui bahwa tingkat efektivitas yang dicapai berdasarkan target dan realisasi atas SP2 sebagai berikut:

a) Pada tahun 2013 yang dicapai adalah sebesar 100\%, maka tingkat efektivitas yang dicapai termasuk dalam kriteria efektif (90$100 \%$ ).

b) Pada tahun 2014 yang dicapai adalah sebesar 100\%, maka tingkat efektivitas yang dicapai termasuk dalam kriteria efektif (90$100 \%$ ).

c) Pada tahun 2015 yang dicapai adalah sebesar 100\%, maka tingkat efektivitas yang dicapai termasuk dalam kriteria efektif (90100\%).

d) Pada tahun 2016 yang dicapai adalah sebesar 100\%, maka tingkat efektivitas yang dicapai termasuk dalam kriteria efektif (90$100 \%)$.

e) Pada tahun 2017 yang dicapai adalah sebesar 100\%, maka tingkat efektivitas yang dicapai

termasuk dalam kriteria efektif (90$100 \%)$.

b. Penghitungan

Pelaksanaan

Berdasarkan

Pemeriksaan

Penghitungan

pelaksanaan

Pemeriksaan dari tahun 2016-2017 adalah sebagai berikut:

1) Tahun 2016

Efektivitas $=\frac{\operatorname{Rp} 7.445 .745}{\operatorname{Rp} 29.440 .524 .488} \times 100 \%=0,03 \%$

2) Tahun 2017

Efektivitas $=\frac{\operatorname{Rp} 540.723 .373}{\operatorname{Rp} 11.000 .000 .000} \times 100 \%=4,92 \%$

Dari hasil penghitungan dapat diketahui bahwa tingkat efektivitas yang dicapai berdasarkan target dan realisasi atas Jumlah Ketetapan Pemeriksaan sebagai berikut:

a) Pada tahun 2016 yang dicapai adalah sebesar $\mathrm{Rp}$ 0,03\%, maka tingkat efektivitas yang dicapai termasuk kriteria tidak efektif $(<69 \%)$.

b) Pada tahun 2017 yang dicapai adalah sebesar Rp 4,92\%, maka tingkat efektivitas yang dicapai termasuk kriteria tidak efektif $(<69 \%)$.

Meskipun terjadi kenaikan pada tahun 2017 dibandingkan tahun 2016 terhadap tingkat efektivitas berdasarkan Jumlah Ketetapan Pemeriksaan namun hasil yang dicapai termasuk dalam kriteria tidak efektif $(<69 \%)$. Persentase ini menunjukkan bahwa meskipun terlihat adanya kerjasama yang kooperatif antara petugas pemeriksa dengan Wajib Pajak baik yang mempunyai penghasilan besar, menengah, dan kecil; tetapi mereka belum memiliki 
tingkat kesadaran dan kepatuhan terhadap kewajiban perpajakannya. Padahal fokus utama dari pemeriksaan adalah Wajib Pajak yang tidak patuh dan yang melakukan penghindaran/penggelapan pajak yang cukup tinggi, yang sebagian besar adalah Wajib Pajak besar dan menengah.

Berarti pihak KPP Pratama Palembang Ilir Barat belum berhasil melakukan pendekatan dengan metode personal persuasif terhadap Wajib Pajak besar dan menengah untuk kooperatif terhadap pelaksanaan pemeriksaan pajak. Yang dimaksud dengan metode personal persuasif adalah dengan melakukan pemantauan ke lapangan dengan melakukan kunjungan langsung ke tempat usaha atau ke tempat tinggal Wajib Pajak untuk melihat kondisi yang sebenarnya terjadi.

\section{Faktor-faktor Mempengaruhi Pemeriksaan}

Pelaksanaan

Faktor-faktor pendukung secara internal dalam pelaksanaan pemeriksaan yaitu:

a. Informasi tentang Wajib Pajak yang jelas, karena ada jaringan yang menghubungkan KPP satu dengan KPP lainnya di seluruh Indonesia, setiap instansi sudah mengirimkan data tiap bulan secara online karena adanya Sistem Informasi Perpajakan (SIP) sehingga pekerjaan KPP Pratama Palembang Ilir Barat lebih cepat dan efisien.

b. Adanya sinergi yang positif antar seksi yang ada di KPP Pratama Palembang llir Barat sehingga datadata yang diperlukan dalam proses pemeriksaan bisa dilaksanakan dengan cepat.

c. Adanya dukungan dari pemeriksa pajak terhadap Wajib Pajak melalui pendekatan persuasif dimana pihak KPP Pratama Palembang llir Barat mengadakan komunikasi dengan beberapa asosiasi yang berdasarkan data yang ada baik intern dan ekstern, dan Wajib Pajak tersebut mau menanggapinya.

d. Laporan SPT harus dilampiri dengan dokumen/catatan/data yang diperlukan oleh KPP Pratama Palembang Ilir Barat, maka dari itu petugas harus menelitinya dengan baik.

e. Sumber daya manusia (SDM) yang cukup dan baik dan mempunyai kemampuan untuk menangani pelaksanaan pemeriksaan.

Faktor-faktor pendukung yang mempengaruhi secara eksternal dalam pelaksanaan pemeriksaan yaitu:

a. Sosialisasi yang cukup gencar di bidang perpajakan yang dilakukan oleh KPP Pratama Palembang Ilir Barat, sehingga kesadaran dari masyarakat mulai tumbuh untuk melaksanakan kewajiban perpajakan secara benar.

b. Adanya kesadaran yang relatif tinggi dan itikad yang baik dari Wajib Pajak yang ditunjukkan melalui kepatuhan dan ketepatan waktu dalam melaksanakan kewajiban perpajakannya, serta sikap kooperatif yang ditunjukkan dalam proses pemeriksaan yaitu dengan memperbolehkan pemeriksa masuk ke dalam ruangan yang dianggap penting untuk mendukung pelaksanaan pemeriksaan, mau meminjamkan

catatan/dokumen/buku kepada petugas pemeriksa, memberikan keterangan kepada pemeriksa secara jelas baik lisan maupun tertulis.

c. Tumbuhnya good and clean governance, yang mana KPP Pratama Palembang Ilir Barat dalam 
melaksanakan pemeriksaan berpedoman pada peraturan Undang-undang perpajakan yang berlaku dan melaksanakan tugas dengan sebaik-baiknya dan penuh rasa tanggungjawab.

d. Adanya kerjasama yang baik antara KPP Pratama Palembang Ilir Barat dengan Pemerintah Kota Palembang jika ada Wajib Pajak yang pindah alamat tanpa memberitahukan kepada pihak KPP Pratama Palembang Ilir Barat, dengan Kantor Bea Cukai untuk mengetahui tentang kegiatan yang dilakukan oleh Wajib Pajak berkaitan dengan kegiatan usahanya bersama bea cukai, dengan Kepolisian jika pada saat pemeriksa melakukan pemeriksaan mendapatkan perlakuan yang tidak baik dari Wajib Pajak dan bersifat untuk melindungi pemeriksa, dengan Imigrasi jika sewaktu-waktu Wajib Pajak melarikan diri karena menolak untuk diperiksa oleh KPP Pratama Palembang Ilir Barat.

\section{Upaya-upaya yang Dilakukan KPP Pratama Palembang Ilir Barat dalam Mengatasi Hambatan yang Terjadi}

Beberapa upaya yang dilakukan oleh KPP Pratama Palembang Ilir Barat dalam mengatasi masalah tersebut, yaitu:

a. Adanya pengajuan penambahan jumlah pemeriksa kepada kantor pusat sebanyak 6 (enam) orang pada tahun 2017, yang diharapkan bisa mengoptimalkan penerimaan negara meskipun jumlahnya tidak besar.

b. Prosedur pemeriksaan yang tidak berbelit-belit, dilakukan perpanjangan dalam menyelesaikan kewajiban perpajakannya, dan ketetapan secara jabatan. c. Menambah sosialisasi yang berkesinambungan kepada Wajib Pajak, yang mana Seksi Penyuluhan dan seksi terkait lainnya di KPP Pratama Palembang Ilir Barat khususnya yang mengurusi PPh Orang Pribadi menyebarkan undangan untuk Wajib Pajak melalui Kantor Pemerintah Kota Palembang, atau Wajib Pajak langsung datang ke Kantor KPP Pratama Palembang Ilir Barat.

d. Sistem penghargaan dan hukuman secara konsisten bagi setiap fiskus, diharapkan untuk memberikan motivasi kerja dan sekaligus sebagai alat monitoring dalam melaksanakan tugas.

\section{KESIMPULAN DAN SARAN}

A. Kesimpulan

Berdasarkan uraian dari hasil penelitian dan pembahasan, maka dapat diberi simpulan sebagai berikut:

1. Hasil penghitungan efektivitas pelaksanaan pemeriksaan berdasarkan Surat Perintah Pemeriksaan (SP2) yang selesai, dimana tahun 2013-2017 mempunyai tingkat efektivitas yang sama yaitu dalam kriteria efektif dengan persentase $100 \%$..

2. Hasil penghitungan efektivitas pelaksanaan pemeriksaan berdasarkan Jumlah Ketetapan Pemeriksaan, dimana tahun 20162017 mempunyai tingkat efektivitas tidak efektif $(<69 \%)$ dengan persentase $0,03 \%$ di tahun 2016 dan 4,92\% di tahun 2017.

3. Faktor-faktor pendukung secara internal dalam pelaksanaan pemeriksaan yaitu:

a. Informasi tentang Wajib Pajak yang jelas, karena ada jaringan yang menghubungkan KPP satu dengan KPP lainnya di seluruh Indonesia. 
b. Adanya sinergi yang positif antar seksi yang ada di KPP Pratama Palembang Ilir Barat.

c. Adanya dukungan dari pemeriksa pajak terhadap Wajib Pajak melalui pendekatan persuasif.

d. Laporan SPT harus dilampiri dengan dokumen/catatan/data yang diperlukan oleh KPP Pratama Palembang Ilir Barat.

e. SDM yang cukup dan baik dan mempunyai kemampuan untuk menangani pemeriksaan.

4. Faktor-faktor pendukung yang mempengaruhi secara eksternal dalam pelaksanaan pemeriksaan yaitu:

a. Sosialisasi yang cukup gencar di bidang perpajakan yang dilakukan oleh KPP Pratama Palembang Ilir Barat.

b. Adanya kesadaran yang relatif tinggi dan itikad yang baik dari Wajib Pajak yang ditunjukkan melalui kepatuhan dan ketepatan waktu dalam melaksanakan kewajiban perpajakannya, serta sikap kooperatif yang ditunjukkan dalam proses pemeriksaan.

c. Tumbuhnya good and clean governance, yang mana KPP Pratama Palembang Ilir Barat dalam melaksanakan pemeriksaan berpedoman pada peraturan Undang-undang perpajakan yang berlaku dan melaksanakan tugas dengan sebaik-baiknya dan penuh rasa tanggungjawab.

d. Adanya kerjasama yang baik antara KPP Pratama Palembang Ilir Barat dengan Pemerintah Kota Palembang, Kantor Bea Cukai, Kepolisian, dan Imigrasi. e. Wajib Pajak yang tiba-tiba pindah alamat tanpa ada pemberitahuan dulu kepada KPP Pratama Palembang Ilir Barat.

\section{B. Saran}

Dari simpulan di atas, ada beberapa saran yang dapat diberikan oleh penulis kepada KPP Pratama Palembang Ilir Barat supaya bisa digunakan dalam meningkatkan pelaksanaan pemeriksaan yaitu:

1. Memaksimalkan sosialisasi dengan pihak-pihak yang terkait dan tertentu mengenai informasi tentang perpajakan terbaru, sehingga diharapkan kesadaran masyarakat atau Wajib Pajak tentang pajak semakin meningkat.

2. Meningkatkan SDM seperti peningkatan kualitas dan kuantitas pemeriksa pajak dengan memberikan kompensasi dan insentif yang mencukupi agar kinerja pemeriksa dapat lebih optimal.

3. Transparansi dalam proses pelaksanaan tugas dan penggunaan penerimaan pajak, sehingga masyarakat atau Wajib Pajak lebih antusias dalam membayar pajak tanpa berfikir yang macam-macam.

\section{DAFTAR PUSTAKA}

Bwoga, Hananta, dkk. 2006. Pemeriksaan Pajak di Indonesia. PT Grasindo. Jakarta.

Direktur Jenderal Pajak. 2013. Peraturan Direktur Jenderal Pajak Nomor: PER-23/PJ/2013 tentang Standar Pemeriksaan Pajak. 
Mardiasmo. 2009. Perpajakan. Edisi Revisi. Penerbit ANDI. Yogyakarta.

Menteri Keuangan Republik Indonesia. 2013. Peraturan Menteri Keuangan Republik Indonesia Nomor: 17/PMK.03/2013 tentang Tata Cara Pemeriksaan.

Moleong, Lexy J. 2011. Metode Penelitian Kualitatif. Remaja Rosdakarya. Bandung.

Nazir, Mohammad. 2011. Metodologi Penelitian. Ghalia Indonesia. Jakarta.

Priantara, Diaz. 2002. Pemeriksaan Pajak dan Penyidikan Pajak, Edisi Pertama. Djambatan. Jakarta.

Republik Indonesia. 2009. Undangundang Republik Indonesia Nomor 6 Tahun 1983 tentang Ketentuan Umum dan Tata Cara Perpajakan Sebagaimana Telah Beberapa Kali Diubah Terakhir Dengan Undang-undang Republik Indonesia Nomor 16 Tahun 2009.

Resmi, Siti. 2014. Perpajakan Teori dan Kasus. Edisi 8. Buku 1. Salemba Empat. Jakarta.

Sedarmayanti. 2009. Sumber Daya Manusia dan Produktivitas Kerja. Mandar Maju. Bandung.

Siagian, Sondang P. 2014. Manajemen Sumber Daya Manusia. Jakarta: Bumi Aksara.

Susanto, Azhar. 2007. Sistem Informasi Manajemen. Lingga Jaya. Bandung. 